Gerd Fritz

\title{
Remarks on the Structure of the Verbal Complex in Early 17th Century German
}

\section{Introduction}

Speakers of various Southern German dialects may be heard to use two syntactic variants of subordinate clauses which are represented by the following Swabian examples:

(1) daß er den net will komme lasse

(2) daß er den net komme lasse will

Of these two variants of the three-element verbal complex, only the non-dialect counterpart of

(2) is accepted as standard modern written German:

(3)

daß er ihn nicht kommen lassen will

In earlier periods of the German language, however, both variants were used by authors of written texts.

Simple facts like these raise the question as to how the grammatical norms of the standard written variety of German came into being and what the earlier stages of this standardization process were. This question has been on the agenda of studies in the history of the German language for some time, but still many details of the emerging picture have to be filled in.

One of the media that are considered to have had great influence on the development of a supra-regional variant of written German are the periodical newspapers which began to appear in the early 17th century and which reached an increasingly large public in the course of the century. The present paper deals with the structure of three-element verbal complexes of the type represented in the above examples as they are to be found in the first two complete annual copies of weekly newspapers in Germany, the Relation (R), printed in Strasburg, and the Aviso (A), probably printed in Wolfenbüttel, both issued in the year 1609 . This paper is meant to serve a double purpose. It is a contribution to the description of the language of the early newspapers and it is a supplement to the valuable work of Härd (1981) who analysed a remarkable cross-section of text types from 1450 to the present without, however, using early newspapers as a source of data. This source provides interesting evidence for a type of text which represents an intermediate level of formality beetween private correspondence on the one hand and literary works and chancery texts on the other. ${ }^{1}$

1 The work presented in this paper is part of a project on the language of the early German newspapers which is supported by the DFG. 


\section{Three-element verbal complexes in subordinate clauses}

\subsection{Position of the finite verb}

\subsubsection{A survey}

In order to provide some background to the special object of inquiry of this paper I shall mention some basic facts about the position of finite elements in subordinate clauses with overt complementizers. By the end of the 16th century clause-final position of a single finite verb is virtually obligatory in written German (cf. Ebert 1986: 105ff.). This applies also to newspaper texts. As far as two-element verbal complexes are concerned it has been shown by a number of authors, including recent work by Ebert, that the sequence non-finite verb form followed by finite form in clause-final position had become more or less the standard sequence in written texts of any kind by the end of the 16 th century. ${ }^{2}$ This result is confirmed by our data. In the whole corpus of the two newspapers (approximately 200,000 words) there are merely six instances of the inverse order (finite + non-finite), five of them modal verbs + infinitive: soll verlieren ( $R$ 210,33), sollen haben (A 71,7; $R$ 143,10), sollen betzalen (A $43,15)$, woll zu stücken hawen ( $R$ 193,21), darvon sind kommen ( $R 189,1)$. There is no indication of a particular dialectal distribution of these items in our texts, so that there is not much more to be said than that this alternative is still available, probably as a marked option but not ungrammatical.

Against this background the data for three-element verbal complexes come as a surprise. As for the position of the finite verb within the cluster, all three possible options are represented:

(4) daß sie für vnüberwindlich solle gehalten werden (A 267,19)

(5) daß das Defension Wesen jetzo eingestellt werden solle (A 207,6)

(6) vnd da er von jhn vberwunden solt werden ( $R$ 178,26)

For ease of reference I shall in the following paragraphs use 'type 1 ' for the sequence finite + non-finite + non-finite (cf. (4)), 'type 2 ' for the sequence non-finite + non-finite + finite (cf. (5)) and 'type 3 ' for the sequence non-finite + finite + non-finite (cf. (6)). I shall furthermore use Bech's notation for the degree of dependency within the verbal complex, e.g. $V_{3} V_{2} V_{1}$ for a structure like liegen bleiben läßt (cf. Bech 1955: 63ff.). In those cases where it is useful to formulate the relationships between structures in terms of rules, I shall for practical purposes assume that the basic position of the finite verb is clause-final. This is not meant to prejudice

\footnotetext{
2 Cf. Härd (1981: 18ff.), Ebert (1981).
} 
the question whether one is in fact justified in making this assumption for Early Modern German.

With respect to the kinds of verbs which appear in finite form the relevant verbal complexes can be separated into two major groups, with either auxiliary verbs (haben, sein, werden) or modal verbs in finite form. Within these groups there are further sub-groups which are characterized by the types and combinations of the non-finite forms represented (infinitives, participles). Some of these sub-groups will be dealt with in later sections of this paper.

In quantitative terms the verbal complexes with a finite modal verb form the most important group. The following table shows the number of verbal complexes listed according to the type of position of the finite verb and the respective newspaper from which the items are taken.

$$
\text { verb newspaper type } 1 \text { type } 2 \text { type } 3 \text { total }
$$

$$
\text { dörffen }
$$

A
R

$-$

21

3

(ii)

(iii)

können

A
R

2
2

7
6

$-$

mögen

$\begin{array}{ll}\mathrm{A} & 10 \\ \mathrm{R} & 23\end{array}$

12
8

$\begin{array}{ll}- & 9 \\ - & 8\end{array}$

(iv)

müssen

$\begin{array}{lllll}\mathrm{A} & 1 & - & - & 1 \\ \mathrm{R} & - & 2 & - & 2\end{array}$

(v)

sollen

$\begin{array}{cc}\text { wollen } & \mathrm{A} \\ & \mathrm{R} \\ \text { total } & \mathrm{A} \\ & \mathrm{R}\end{array}$

A $\quad 33$

R

62

52

$\begin{array}{ll}1 & 86 \\ 3 & 97\end{array}$

$\begin{array}{ccccc}\mathrm{A} & 2 & 16 & - & 18 \\ \mathrm{R} & 4 & 2 & 1 & 7\end{array}$

$\begin{array}{lllll}\text { A } & 49 & 89 & 3 & 141 \\ \text { R } & 91 & 51 & 5 & 147\end{array}$

A first look at these statistics shows at least two interesting facts. Apart from the verbs dörffen and müssen, where the numbers are just too small to yield significant results, both newspapers contain considerable numbers of both type 1 and type 2 structures, with an additional small number of type 3 examples. The proportion of type 1 items vs. type 2 items is significantly different in $A$ and $R$, most obviously in the case of sollen, where $\mathrm{R}$ shows nearly two thirds of type 1 vs. one third of type 2, whereas A shows nearly the inverse proportion. 
Before we go into a detailed discussion of these data I shall present the corresponding figures for auxiliary verbs in table (8).

$\begin{array}{llcccc}\text { verb } & \text { newspaper } & \text { type } 1 & \text { type 2 } & \text { type 3 } & \text { total } \\ \text { sein } & \text { A } & 1 & 1 & - & 2 \\ & \text { R } & 1 & 1 & - & 2 \\ \text { haben } & \text { A } & 10 & - & 1 & 11 \\ & \text { R } & 7 & - & - & 7 \\ \text { werden } & \text { A } & 9 & 1 & 1 & 11 \\ & \text { R } & 6 & - & 1 & 7\end{array}$

The most striking aspect of this table is the virtual absence of three-element verbal complexes with the auxiliary verb sein and the scarcity of examples with haben. An additional fact, not shown in this table, is that all 4 instances of sein occur in the subjunctive mood as exemplified in (9) and (10):

(9) gehandelt worden sey (R 207,3)

(10) weren außgeschafft worden ( $R$ 32,27)

The explanation of the absence of structures with sein is the fact that the passive construction sein + worden + past participle generally appears as a so-called afinite construction, i.e. with ellipsis of the finite form of sein (11). It is probably for reasons of semantic perspicuity that the authors of our texts sometimes prefer to use the explicit finite form if the subjunctive mood is involved. Not to the same extent but still very frequently the constructions with haben are used in an elliptical form (cf. (12)).

gefangene Vngern (welche bißhero fleissig geprügelt worden) (A 358,26)

As a consequence of these observations, we have to extend our typology and include as type 4 the afinite (elliptical) type of verbal complex. It is, of course, useless to speculate which position the finite verb haben or.sein would have taken up if it had been inserted. The afinite construction simply is a characteristic and frequent type of verbal complex sui generis and as such a typical marker of subordinate clauses in texts of this period. ${ }^{3}$

Of the approaches generally adopted in accounting for this kind of data three will be used in the following interpretation, viz. the analysis of structural factors, the inspection of dialect factors and the search for stylistic factors.

3 Cf. Admoni (1967: 190f.). 


\subsubsection{Structural factors}

The first structural factor is of course the syntactic category of the finite verb. Leaving aside the afinite constructions we find an overwhelming preponderence of type 1 constructions both with haben and werden which together with sein are generally considered to be auxiliary verbs. In this group there is no significant difference between the newspapers $A$ and $R$. So the normal word-order type seems to have been $V_{1} V_{2} V_{3}$ (cf. (13) and (14)), with the marked options $V_{3} V_{2} V_{1}(15)$ and $V_{3} V_{1} V_{2}(16)$ and (17).

weil der König eo acte hab schließen müssen (A 87,15)

daß man [...] wird kommen können ( $R$ 47,27f.)

da aber $[\ldots]$ suchen lassen würden (A 88,17)

welchen J.M. [...] sein Jus fürbringen werden mögen (A 198,13)

In modern standard written German there is the well-known rule - or, rather, combination of rules - that in the pattern main verb (infinitive) + modal verb (past participle) + haben (finite) the past participle of the modal is infinitivized and the finite verb is moved to the left of the first non-finite satellite of the finite verb. ${ }^{4}$ Whereas both rules are obligatory in the case of dependent modal verbs $\left(V_{2}\right)$, the inversion rule is optional for a number of other verbs, including lassen. There is furthermore a similar optional inversion rule for the pattern double infinitive + finite form of future-werden. Applications of these rules are shown in the following examples:

$$
\begin{aligned}
& \text { *daß man es sehen gekonnt hat } \\
& \text { daß man es hat sehen können } \\
& \text { *daß man ihn kommen gelassen hat } \\
& \text { daß man ihn kommen lassen hat } \\
& \text { daß man ihn hat kommen lassen } \\
& \text { daß man kommen können wird } \\
& \text { da } \beta \text { man wird kommen können }
\end{aligned}
$$

Apart from a number of exceptions which will presently be mentioned, our early 17 th century data are basically compatible with these rules. In addition to the double infinitive cases (socalled Ersatzinfinitiv) with modals, the cases of haben (finite) + lassen also show infinitivized participle and inversion of the finite verb:

$$
\text { weil etliche Türckische Tartanen sich vmb Corsica haben sehen lassen ( } R \text { 216,21) }
$$

There are, however, no items of type 2 attested so that one could conclude that the inversion rule is obligatory, if only in the weaker form that produces $\mathrm{V}_{3} \mathrm{~V}_{1} \mathrm{~V}_{2}$. In the case of finite werden the inversion rule is not just optional - which of course it is - but indeed the preferred

\footnotetext{
${ }^{4}$ Cf. Behaghel (1924: 366ff.), Reis (1974), den Besten/Edmondson (1983).
} 
choice and, therefore, probably the unmarked option. Contrary to modern written German the optional inversion rule also extends to the finite forms of sein, yielding both the structures $\mathrm{V}_{3} \mathrm{~V}_{2} \mathrm{~V}_{1}(26)$ and $\mathrm{V}_{1} \mathrm{~V}_{3} \mathrm{~V}_{2}(27)$ :

$\mathrm{da}$ die Confession [...] auch in die Landtaffel einverleibt worden were (A 66,9) das die Jesuitter daselbst auch weren außgeschafft worden ( $R$ 32,27)

These facts justify a first generalization: in the case of the auxiliaries the inversion rule has a wider range of application than in modern written German.

This generalization can even be extended if we take into consideration finite modal verbs. Quantitatively, the most conspicuous difference in our field of enquiry between present day written texts and our 17 th century data is the presence of a high percentage of type 1 clusters, as is amply shown in the table 7 . In other words, the optional inversion rule also applies to modals, which, as we already noted, is not the case in modern written German.

Among the sub-patterns of this pattern there is one that shows a somewhat extreme quantitative distribution, viz. the combination modal verb (finite) + lassen + infinitive (e.g. wollen passiren lassen). Here we find a notable prevalence of type 2 sequences (e.g. tauffen lassen mögen) in $\mathrm{A}$, as the following table shows:

$$
\text { type } 1 \quad \text { type } 2 \quad \text { type } 3
$$

$\begin{array}{llll}\mathrm{A} & 4 & 25 & 1 \\ \mathrm{R} & 8 & 5 & 1\end{array}$

It is interesting to note that this combination, Härd's subtype VIb, is considered to be one of the two patterns which tend to be particularly prone to finite-final position in the course of the 17th century (cf. Härd 1981: 90). Why this is so is hard to say. Härd's explanation for the trend he diagnoses is that modal verbs bear more semantic weight than auxiliaries and, therefore, tend to sentence-final position. One might prefer syntactic parlance and consider the factor to be main-verb likeness (cf. den Besten and Edmondson 1983: 190f.). But still the explanation is not very revealing. Anyway, it is remarkable that Härd's second candidate for an early trend towards finite-final position, his subtype III (finite modal verb + past participle + infinitive: solle bezahlt werden), shows a high percentage of finite-first occurrences in our texts. And as realizations of this sub-pattern comprise the majority of three-element verbal complexes in our data the newspaper texts give the general surface appearance of a wellestablished $V_{1} V_{3} V_{2}$ type. 


\subsubsection{Dialect factors}

The attribution of certain statistical properties of our texts to factors of dialect calls for a very circumspect and cautious analysis. In the first place it is not obvious to what extent regional correspondents, say from Prague or Antwerp, were in fact natives of those regions and, if so, to what extent they made use of or avoided regionalisms. Secondly, it is hard to determine to what extent the editors and printers actually corrected the incoming newsletters from their correspondents and if they did, to what extent they themselves showed influences of regional dialect.

A close examination of all three-element verbal complexes in relation to their source of correspondence shows no significant pattern of distribution. On the other hand, the difference between $A$ and $R$ in the relative frequency of type 1 sequences is so striking that it seems justified to attribute the high percentage of type 1 items to the Alsatian dialect of the editor and/or printers of $\mathbf{R}$. A comparison with texts written by authors from Alsatia, though of a somewhat later period (Moscherosch 1660 and the "Lapis mineralis" from 1681), seems to confirm the hypothesis that a high percentage of type 1 sequences is characteristic of an Alsatian version of 17th century written German (cf. Härd 1981: $75 \mathrm{ff}$.). There is a possible competing factor which should at least be mentioned at this point. There is evidence for the middle of the 17th century that type 1 sequences were considered more formal than type 2 sequences (cf. Härd 1981: 90). If this attitude could be traced back to the beginning of the century we might be landed with an additional factor to account for our statistics. This would go well with the generally more formal, booklike appearance of $\mathrm{R}$ as compared to the more informal presentation of $A$. However, this is rather speculative and we are not on very firm ground if we want to make a final decision as to which of the factors or to what proportion of respective influence of both factors the particular statistical data of $R$ should be attributed. If I had to place a bet I should place it on dialect.

As for newspaper $\mathrm{A}$, the statistical data are compatible with the data from other contemporary texts from the Augsburg/Nuremberg region, but they are not specific to such an extent that one could count them as a final linguistic confirmation of the Augsburg or Nuremberg provenience of this newspaper. It looks as if such a confirmation were not forthcoming on the basis of any of the linguistic variables.

There is a further type of data that can be accounted for by the dialect background of the newspapers, i.e. the type 3 sequences which by the end of the 16th century had become a minority pattern in written texts. There is evidence that by 1609 they were considered strongly dialectal and/or archaic in written German. As far as this type of verbal complex does appear in early 17th century texts, it seems to be limited to Bavarian, Swabian and Alemannic texts. Although the number of items in our data is fairly low (11 items), it seems 
obvious that newspaper editors or printers did not make a systematic effort to get rid of dialectal forms.

\subsubsection{Stylistic factors}

One possible stylistic factor has already been mentioned in the preceding section, the factor of formality. Two more specific factors shall now be taken into account. The first is the factor of rhythm which has generally been considered an important if sometimes slightly elusive factor. In our texts there is one set of data that arouses the suspicion that some factor of rhythm might be involved. Newspaper A shows a distinct disinclination to use type 1 sequences if the finite modal verb is monosyllabic sol(l) as opposed to bisyllabic solle and sollen. There are 3 occurrences of type 1 with sol $(l)$ as compared to 15 of type 2 . Unfortunately, closer inspection does not reveal any correlation to particular rhythmical patterns, so that our suspicion cannot be substantiated. We fare better with another factor, length of constituents. Here there emerges at least one distinctive pattern in which preference for early placement of the finite verb can be shown. In coordinative structures with ellipsis of werden in the first conjunct and ellipsis of the finite verb in the second conjunct the finite verb tends to be placed in the first position of the complex, with the past participle following suit and werden in clause-final position: 5

weil offtmal hohe Potentaten durch böse friedhessige Räth können verleitet $v$ nd in Vngelegenheit geführet werden (A 67,8)

$\mathrm{da}$ gemelter Brief den Ständen ehe nicht solle gefolgt $\mathrm{vnd}$ in die Landtaffel einverleibt werden (A 206,35)

[...] zuberathschlagen / was gestalt die Stadt Thonowerth / wieder vnter denselben Craiß möchte gebracht / vnnd dem Bayerfürsten aus der Handt gerissen werden (A 77,4)

The early placement of finite verb + past participle could be described as a kind of 'exbraciation', which is generally considered a means of increasing comprehensibility in structures with complex complements. So in these cases we have fairly good candidates for a stylistic account of the preference for type 1 sequences. Although the numbers are not very impressive, this kind of stylistic strategy could be seen as a minor stabilizing factor in the preservation of type 1 complexes.

It is, incidentally, an interesting fact that these examples form the only group worth mentioning of constructions where an additional constituent is placed within the verbal group. There are two more isolated instances of embraced constituents, in one case a pronoun (32) and in the other an adverb (33):

5 Similar constructions are to be found in R 55,1; R 170,22; A 254,27. 
weil [...] nicht hetten derselben beywohnen können (A 138,29)

daß sie [...] weren bißhero abgehalten worden (A 167,8)

There is one statistical reason why the number of candidates for constructions with a nominal complement inserted within the verbal group is not very high, viz. the high proportion of passive constructions among the relevant structures. But it is still surprising that we do not find verbal complexes like (34) or (35) which were not almost certainly ungrammatical:

\section{daß sie jhre Söhn sollen zu Padua studieren lassen}

welche dann sollen im Römischen Glauben vnterrichtet werden

So the basic principle seems to have been to have the verbal elements in uninterrupted sequence at the end of the subordinate clause. In other words, restructuring processes within the verbal complex did not involve non-verbal constituents to the extent they do in some of Lötscher's (1978) data from modern Southern German dialects.

\subsection{The order of the non-finite elements}

In the vast majority of cases the sequence of the non-finite elements is $V_{3} V_{2}$, either in the combination $\mathrm{V}_{1} \mathrm{~V}_{3} \mathrm{~V}_{2}(36)$ or in the combination $\mathrm{V}_{3} \mathrm{~V}_{2} \mathrm{~V}_{1}$ (37):

daß sie für vnüberwindlich solle gehalten werden (A 267,19)

There is one example of the inverted sequence $V_{2} V_{3}$, the $V_{1} V_{2} V_{3}$ pattern in (38), as opposed to the normal sequence of this type (39):

The exceptional item in (38) belongs to the category which Härd (1981: 97f.) notes as the only $V_{1} V_{2} V_{3}$ pattern to appear with any frequency in 17 th century texts, the pattern haben + modal verb + main verb with prefix or complement. It may be noted in passing that this particular item is taken from the only correspondence originating from Erfurt. So it is not altogether unlikely that this example might be accounted for by a Northern German regional preference. It is worth noting that this type shows a superficial resemblance to the fourelement type $\mathrm{V}_{1} \mathrm{~V}_{2} \mathrm{~V}_{4} \mathrm{~V}_{3}$ (hat wollen befinden lassen). Maybe this resemblance contributed to the survival of the otherwise isolated pattern.

As we have seen, $V_{3}$ and $V_{2}$ are normally in adjacent positions. This makes them potential candidates for the reanalysis operation which has recently been advocated by several authors (cf. den Besten and Edmondson 1983, von Stechow and Sternefeld 1988). Things are slightly more complicated for four-element sequences, where an additional cycle of reanalysis is called for. The most difficult pattern to explain is obviously our type 3. A simple solution 
could be to assume an additional local movement after $V_{3}, V_{2}$, and $V_{1}$ have become members of one constituent. But maybe this solution is just too simple.

\section{Four-element verbal complexes}

Four-element verbal complexes are not very frequent in our corpus. They are, however, numerous enough for us to be able to differentiate four distinct types.

The first type ( 2 items) has the structure $V_{1} V_{4} V_{3} V_{2}$ :

50000. Taler / so dem Orator / zu Ofen / sollten erlegt worden sein (A 60,25f.)

The finite verb is positioned at the beginning of the cluster, and the non-finite elements follow in inverted order of dependency $\mathrm{V}_{4} \mathrm{~V}_{3} \mathrm{~V}_{2}$. In modern standard German the corresponding combination has the sequential structure $\mathrm{V}_{4} \mathrm{~V}_{3} \mathrm{~V}_{2} \mathrm{~V}_{1}$, viz. the inverted order of dependency is carried through:

weil der Brief geschrieben worden sein soll

The second type, the most frequent pattern (6 items), conforms to the structure $V_{1} V_{2} V_{4} V_{3}$ : haben wollen befinden lassen (A 180,26)

Here the finite verb is also in leftmost position with the next element in the order of dependency following suit. Whereas in modern standard German this sequence is only usual for three infinitives as non-finite verbal forms our data show this sequence also in the case of a past participle in the non-finite cluster: 6

welche $[. .$.$] haben sollen geführt werden ( \mathrm{R} 43,10 \mathrm{f}$.)

The third type ( 2 items) has the structure $\mathrm{V}_{4} \mathrm{~V}_{1} \mathrm{~V}_{3} \mathrm{~V}_{2}$ :

$$
\mathrm{daß}[\ldots] \text { nur in beysein der Herrn directoren verlesen hat werden sollen }(\mathrm{R}
$$

This type is a close relative of the first type, with the single difference that the basic order of non-finite elements $V_{4} V_{3} V_{2}$ is interrupted by the interposition of $V_{1}$. This yields a four element counterpart of the 'compromise' type $3\left(V_{3} V_{1} V_{2}\right)$ among the three-element complexes. Finally, there are also afinite constructions in this category as there are in the category of three-element structures. These show basically the same order of non-finite elements as their counterparts with a finite verb, $V_{4} V_{3} V_{2}\left(5\right.$ items, e.g. (45)) and $V_{2} V_{4} V_{3}(2$ items, e.g. (46)):

\footnotetext{
${ }^{6}$ Cf. Engel (1988: 446).
} 
Finally, there are also afinite constructions in this category as there are in the category of three-element structures. These show basically the same order of non-finite elements as their counterparts with a finite verb, $V_{4} V_{3} V_{2}\left(5\right.$ items, e.g. (45)) and $V_{2} V_{4} V_{3}(2$ items, e.g. (46)):

Als sie sich nicht vertreiben lassen wollen (A 101,17)

In all cases the ellipsis concerns the finite form of haben.

To summarize these findings, the finite verb is generally positioned at the beginning of the verbal complex - with one exception where it is inserted after the first non-finite element -, and the non-finite part always contains the sequence $\mathrm{V}_{4} \mathrm{~V}_{3}$, with $\mathrm{V}_{2}$ either staying in final position or following the finite verb to the beginning of the complex, however in inverted order $V_{1} V_{2}$. A comparison with the three-element structures shows that now there is no option for the finite verb to stay in sentence-final position and that $V_{4} V_{3}$, which corresponds to $V_{3} V_{2}$ in the three-element structures, is the only pattern represented in our data. The optional position of $V_{2}$ seems to correspond to the optional position of the finite verb in the three-element complexes. The main difference between this system and modern standard German is, of course, that modern German allows the finite verb in sentence-final position, at least in those cases where there is no cluster of infinitives.

\section{Concluding remarks}

The general impression conveyed by our data is that in our type of written texts from the beginning of the 17th century there is a fairly stable system of type 1/type 2 options for all cases of three-element verbal complexes with a finite modal verb. In those cases where the finite verb is an auxiliary the type 2 (or type 3 ) option is obviously a marked option. As for the four-element complexes, finite-first within the verbal complex is obligatory. The remarkable thing about this system is its stability in face of heavy competition from the oneand two-element verbal structures which almost exclusively conform to the principle of clause-final position of the finite verb. Whereas in the development of standard written German the type 1 option for structures with finite modal verbs lost ground in the course of the 18th century, many German dialects have preserved a system of options comparable to the one represented in our data. As the examples quoted in Lötscher (1978) show, some presentday dialects are, in addition, much less restrictive as to the placement of nominal elements within the verbal chain. So the structure of the verbal complex in our data already looks like the product of a standardization process for supra-regional written German. A stabilizing factor for the type 1 option could be seen in a superficial relatedness to structures in main 
sentences and subordinate clauses without overt complementizer, as in the following sentence types:

Dieselben Soldaten sollen abgedanckt werden man vermut / die Evangel. Bücher möchten colligirt werden

From this point of view the $V_{1} V_{3} V_{2}$ sequence looks like a small brace construction which could be reinforced by its counterpart in main sentences. Admittedly this is not very strong even as a partial explanation. Even less convincing is an explanation in terms of reduction of perceptual load. The comparison of $V_{1} V_{2} V_{3}$ with $V_{3} V_{2} V_{1}$ does not present an impressive gain in perspicuity of construction as in the case of the exbraciation of complex nominal constituents in main sentences which is the prototype of a movement of constituents which can be seen to improve comprehensibility.

As for the SOV question, I do not think any far-reaching conclusions can be drawn from the data presented in this paper. The fact that the non-finite verbal forms follow the finite verb seems to argue against SOV. On the other hand, the fact that the verbal complex always takes the form of a continuous constituent without interposition of nominal constituents provides the champion of SOV with the argument that it is the whole complex and not just the finite verb that takes up the characteristic verb-final position.

\section{Bibliography}

Admoni, W.G. (1967): "Der Umfang und die Gestaltungsmittel des Satzes in der deutschen Literatursprache bis zum Ende des 18. Jahrhunderts." - In: Beiträge zur Geschichte der deutschen Sprache und Literatur (Halle) 89, $144-99$.

Bech, G. (1955): Studien über das deutsche verbum infinitum. Vol. 1. - Det Kongelige Danske Videnskabernes Selskab. Dan. Hist. Filol. Medd. 35.2. Kopenhagen.

Behaghel, O. (1924): Deutsche Syntax. Vol. II. - Heidelberg.

den Besten, H. \& J.A. Edmondson (1983): "The Verbal Complex in Continental West Germanic." - In: W. Abraham (ed.): On the Formal Syntax of the Westgermania (Amsterdam/Philadelphia) 155-216.

Ebert, R.P. (1981): "Social and Stylistic Variation in the Order of Auxiliary and Nonfinite Verb in Dependent Clauses in Early New High German." - In: Beiträge zur Geschichte der deutschen Sprache und Literatur 103, 204-237.

Ebert, R.P. (1986): Deutsche Syntax 1300-1750. - Bern/Frankfurt am Main/New York.

Engel, U. (1988): Deutsche Grammatik. - Heidelberg.

Härd, J.E. (1981): Studien zur Struktur mehrgliedriger deutscher Nebensatzprädikate. Diachronie und Synchronie. - Göteborg (= Göteborger Germanistische Forschungen 21). 
Lötscher, A. (1978): "Zur Verbstellung im Zürichdeutschen und in anderen Varianten des Deutschen." - In: Zeitschrift für Dialektologie und Linguistik 45, 1-29.

Reis, M. (1974): "Syntaktische Hauptsatzprivilegien und das Problem der deutschen Wortstellung." - In: Zeitschrift für Germanistische Linguistik 2, 299-327.

Schöne, W. (1939): Der Aviso des Jahres 1609.- Leipzig.

Schöne, W. (1940): Die Relation des Jahres 1609. - Leipzig.

von Stechow, A. \& W. Stemefeld (1988): Bausteine syntaktischen Wissens. - Opladen. 


\section{Who Climbs the \\ Grammar-Tree}

Herausgegeben von

Rosemarie Tracy

Max Niemeyer Verlag Tübingen 1992 